On the principle that public pressure on autonomous corporations is always constructive, the Campaign for Better Broadcasting should be a useful service. In many ways, there are obvious faults to be remedied. It is, however, sad that a group of people with such weight as those who have formed the campaign should have started from such a narrow base. To complain about the content of existing sound broadcasting services without considering the way in which the whole pattern of broadcast telecommunications may be changed by technical developments well on the way is to grasp the wrong end of the stick.

With the arrival of communications satellites and the development of cable television services, it has become clear that it is now technically possible to increase enormously the number and the diversity of broadcast. ing channels. In principle, there is no reason why people should not in future be given access not merely to the television programmes put out by local broadcasting authorities but also to those broadcast elsewhere, in neighbouring countries perhaps. Satellites make possible long distance communication. Cables permit local distribution without interference. Although the cost of operating some schemes like this would no doubt often be a brake on the speed with which they were developed, the time is fast approaching when organizations such as the BBC will supply only a part of the content of the television broadcasts which capture loca] interest (and will, by the same test, find themselves broadcasters in the export business).

In circumstances like these, it is inevitable that there should be a separation of the functions which broadcasting authorities such as the BBC have put together. Deciding the content of programmes and then designing them is one job. Making the corresponding electromagnetic signals available to those who wish to have them is another. Most probably the most desired improvement in television and sound broadcasting alike would be an increase in the number of channels available to ordinary people. This, unfortunately, is something which the BBC has shied away from in its planning for the future, partly because it is accustomed to living on a tight budget and partly because it shrinks from schemes for raising revenue independently of the licence fee which is paid by owners of radio and television receivers. To be sure, there is to be a scheme for the development of local radio in Britain and much of the BBC's new plans seem to have been designed so as to get local radio quickly off the mark. (If local broadcasting is much delayed, there is always the chance that the commercial radio stations which the Conservative Party is attached to would steal the BBC's thunder.) But the Campaign for Better Broadcasting would have now a better claim on public attention if it had given more weight to the prospects for diversity which are opened up by new technical developments in telecommunications. And in the long run, of course, it may be that the coexistence of independent broadcasting channels may be a better assurance of quality of broadcast programmes than any amount of propaganda.
TELECOMMUNICATIONS

\section{Advice for Intelsat}

ONE trouble with being a pioneer is that nobody can give you advice. At last Intelsat (International Telecommunications Satellite Consortium) has been offered some in a form that it may be able to take. A study group, hung with the inevitable label of "task force", under the auspices of the Twentieth Century Fund has prepared some recommendations, legally and technically sound and politically neutral, which the 68 members of Intelsat would do well to digest before re-convening in. Washington in November. Then they must try to do what they failed to do in February - organize themselves into a permanent body to run the world's commercial satellite network.

Intelsat should be pleased with the verdict that it is the best mechanism for providing the entire world satellite communication cheaply and efficiently. That may make it accept more easily the fund's recommendation that it expand itself into something bigger and more flexible than its present narrow circuitselling form. Intelsat, the advisers recommended, should provide a much wider range of satellite communication services--it should do local and regional communications for those who want them. It should take in as members organizations such as the World Meteorological Organization as well as nation states; it should, accordingly, sell meteorological and navigation services and it should, above all, take some interest in the content of satellite signals-belping educational television in underdeveloped countries, for example -instead of contenting itself to be a passive signal carrier.

Even on the purely commercial basis on which it is operated, under the managership of the American Comsat (Communications Satellite Corporation) since 1964, Intelsat should become much more imaginative. Rates should be flexible. As things stand, there is a flat fee of $\$ 20,000$ a year for a half-circuit (from an Earth station up to the satellite), no matter where in the world or what time of day. The heaviest traffic is on the North Atlantic run, when it is morning in New York and afternoon in London. If rates were lowered for New York afternoons this might encourage telephone traffic to South America, where it is also afternoon. Independently, rates could also be lowered on the Indian Ocean satellite, where traffic is light and needs to be developed.

Two structural changes are needed above all. Comsat should not remain as manager; no entity with a national identity should run what is the most international form of communication yet developed. No one country should have the right of veto, as the United States does now. And most crucial of all, countries which belong to Intelsat should not be represented by their telecommunications organizations, but by a broadly based committee representing the many interests within the country in communications. The curse of Intelsat has been its sober dedicated telecommunications men. As Mr Fred Friendly, the American pundit, has recorded, an executive of the British Post Office told him in 1965: "Let me assure you that the Post Office is in the satellite business for one purpose, to make as much money as it can by moving telephone message units." 
Among the other recommendations made in the report were that Intelsat should develop new suppliers in as many countries as possible, but that if their prices were higher than the American, the government concerned and not the satellite users should pay the difference. Non-members (Russia and others) should be encouraged to use the Intelsat system. The developed countries should try to help the poorer countries to plan their total communication networks and the International Telecommunications Union at Geneva, an under-appreciated agency of the United Nations, should be strengthened in order that it should be possible to supervise more effective use of the radio frequency spectrum.

Most of the members of the Twentieth Century Fund's task force were American. They will be joined by communications experts from other countries, including Russia, at a conference near Geneva later this month. Under the joint sponsorship of the fund and the Carnegie Endowment for International Peace, the conference will discuss how international organizations should handle the regulation of communications in outer space. All this flurry of thought on satellite communications is in anticipation not only of Intelsat's negotiations but of the ITU's World Radio and Space Communications Conference in 1971, and also of the advent of the next generation of satellites (Intelsat 4) which, early in the $1970 \mathrm{~s}$, are each going to make available 6,000 circuits, 18,000 telephone circuits or 36 international television channels to a relatively unprepared world.

\section{TELESCOPES}

\section{Dim Seeing in Saudi Arabia}

\section{from our Astronomy Correspondent}

A CRITICAL stage has been reached in the negotiations to set up an observatory with a 200 inch optical telescope near. Riyadh in Saudi Arabia, according to Professor Robert Seeds of the University of Riyadh, who has been in London this week making an informal approach to the Export Credits Guarantee Department of the Board of Trade. The hope is that the ECGD will be able to guarantee credit to pay for the telescope and the observatory buildings, but according to the ECGD no firm proposal has yet been put to it.

If the project gocs ahcad, the telescope will be the largest outside the Soviet Union, where a 236 inch instrument is being built in the Caucasus. To bolster Saudi pride the diameter of the Riyadh mirror is planned to be fractionally larger than the 200 inch of the Hale telescope on Palomar Mountain. Unlike the Sovict instrument, which is believed to be running into problems stemming from the choicc of an altazimuth mounting, the mounting of the Riyadh telescopo would be on conventional lines.

But the outlook for the project is less optimistic than when it was first mooted early in 1967. The war with Israel, a subsidy of $£ 80$ million to Egypt while the Suez Canal is closed, and a series of civil engineering works have all conspired to make the Saudi Government less inclined to put forward the money than it was originally. But, like the British Government talking about the CERN $300 \mathrm{GeV}$ machine, the Saudi Arabian Government apparently likes to say what a splendid idea the project is if only it could put off the spending of money.

Professor Seeds hopes the ECGD will be able to help it do just that, and still make a start on the construction as soon as possible. Since early this year, the indications have been that the government does not want to put down any money on the project for the next four years, and the role of the ECGD would be to tide the project over until then. The observatory would then, of course, be British built, as the job of the ECGD is to guarantee credit for the purchase of British exports.

According to Professor Seeds, there is a good chance that the ECGD will regard the project sympathetically, but one of the conditions is likely to be a large down payment from Saudi Arabia in the third year of the project, earlier than the government wants. Professor Seeds therefore hopes he can persuade the ECGD to modify its demands.

Before the position changed earlier this year, the Government of Saudi Arabia was to allocate $f 11$ million to the project, the rest coming from the University at Riyadh. At present, plans for the observatory are being drawn up using the funds of the university to finance the low level of work currently going on. The telescope is of more than passing interest to British astronomy because the intention is for it to be in the hands of the Science Research Council for the first five years of its operational life. The final draft of an agreement between the SRC and the University of Riyadh is already in existence, and the arrangement is that the SRC pays for the running costs and supplies maintenance staff and that the telescope is used by astronomers from Britain. When this bargain for the SRC ends, the hope is that the University of Riyadh will be experienced enough to take over the running of the observatory.

As the firm responsible for the Isaac Newton telescope, Grubb Parsons seems a likely contender for the job of building the 200 inch, but there seems little hope of the company being able to provide the finance itself. An alternative is financial support from the United States, which would presumably put the part to be played by British astronomy in jeopardy.

Sir Bernard Lovell plays an almost legendary part in the genesis of the project. Late in 1966, his comments in a BBC World Service broadcast that what astronomy needed was more optical tclescopes in the 150-200 inch range were picked up in Riyadh, and the 200 inch telescope proposal was put forward shortly after. The site has already been fixed by an advisory committee within a hundred metres or so, and the secing conditions have been tested by the AstronomerRoyal.

\section{PARTY CONFERENCES \\ Liberals without Science}

THE annual extravaganza of the party political conferences has come round again. This year, the Liberal Party is the first to go into action. Its conference will take place in Brighton from September 17 to 20 , and the final agenda covers the whole political spectrumexcept for matters concerned with science policy. This is rather surprising because a conference which took place in Nottingham in March produced some 